relation to the calvaria, it is pointed out that an examination of curvatures of the crania show that the Bushman occupies a higher evolutionary place than Cro-Magnon man, and according to one method of study even a higher rung than the European. This latter result, however, is due to the employment of a method which as a measure of fœtalisation points to an extreme specialisation rather than a high status in evolutionary development. In the examination of the pelvis, by Miss Margaret Orford, the results point to the similar indication of specialisation. She concludes that the Bush pelvis is primitive or apelike in many respects; and on the whole the Bush female pelvis exhibits primitive characteristics in more exaggerated form than does the male. The bones are small in absolute measurement, but massive in proportion to their size. The sex differences are well-marked. The Bush pelvis was capable of developing secondary specialisations, such as the exaggerated features of sexual differentiation, the shallow acetabulum, etc. It is, therefore, an intimate admixture of primitive and specialised features.

\title{
Systems of Economic Reform
}

$\mathrm{D}^{\mathrm{u}}$ URING recent years, men in all walks of life have begun to question the present structure of society with its apparently inevitable liability to periodic maladjustments, and in an endeavour to suggest a remedy of present ills, all kinds of proposals have been put forward. The very multiplicity of these plans for economic betterment, however, is bewildering and confusing, even to those who have the time to examine them in some detail. For this reason alone the recent publication by the Engineers' Study Group on Economics of a chart analysing in convenient form the salient features of fourteen different proposals for economic reform should serve a useful purpose. In addition to this chart, the Group, which was formed by a number of engineers and men of science somewhat more than a year ago, has recently prepared a valuable interim report* which examines twenty-four separate sets of proposals, analysing them under three headings, namely, $(a)$ monetary, $(b)$ industrial planning and $(c)$ a combination of industrial planning and monetary. The real division of opinion which this classification is intended to emphasise is that existing between those who think that prosperity can be reached by alterations, radical or otherwise, in the monetary system, and those who believe that some control of industrial production is required. The division is also of importance in respect of immediate practical possibilities. Few if any of the monetary proposals would require elaborate preliminaries, and most of them could be brought into full operation in a comparatively short time. It is otherwise with the schemes which involve planning, as these would almost invariably take time to put into practice.

Most of those who make proposals for economic reforms start with an analysis of the present situation, and there is a considerable difference of opinion as to the main causes of the position, though there is a measure of agreement among certain groups of schemes. Several of the proposals for monetary reform definitely assert that insufficient purchasing power is at present distributed to purchase the goods which are being produced. The supporters of the Consumer Money League and of the Social Credit Scheme of Major Douglas assert that this deficiency is automatic and inevitable; accordingly the Consumer Money League advocates local note issues, while the Douglas proposals suggest remedying the deficiency either by issuing credit to retailers conditionally on sales at regulated prices, or by way of a 'national dividend' to every individual.

* The British Science Guild : Engineers' Study Group on Economics. First Interim Report on Schemes and Proposals for Economic and Social Reforms. Pp. 44. (London: British Science Guild, 6 John Hazlitt House, Chancery Lane, W.C.1: 1935.) 18.
In the opinion of Mr. J. M. Keynes, the deficiency of purchasing power is not necessarily permanent, and his immediate remedy for the present situation is large-scale public works, financed by Government loans. The London Chamber of Commerce suggests the monetisation of commodities by issuing currency against eligible trade bills. Silvio Gesell's 'Demurrage Money' scheme, which involves the elimination of interest, and the Kearney 'True Finance' scheme also assert that there is insufficient purchasing power, but their main remedy is designed to correct this shortage by increasing the velocity of circulation rather than the amount of money.

Two more schemes, those of Lord Melchett and Prof. F. Soddy, diagnose a shortage of effective purchasing power, but do so somewhat less definitely than is the case with the other schemes previously mentioned. Lord Melchett proposes to meet the apparent shortage by monetisation of commodities and by paying off the National Debt by means of bank drafts. Prof. Soddy holds that the shortage is due to the fact that it is to the interest of the bankers who control the issue of money to keep it scarce, and he therefore advocates the nationalisation of the issue of currency and credit and the control of such issues by a scientifically determined price index.

The three remaining monetary schemes examined in the report, namely, those of McGregor, Deane and Sir Basil Blackett, stress lack of balance as being mainly responsible for the present situation. The McGregor plan defines balance as that between spending and saving, and holds that the existing situation is due to over-saving and that it can be rectified by raising or lowering the general salary and wage level by carefully calculated percentages. The Deane plan, which is American in origin, stresses mal. distribution of purchasing power resulting from technological unemployment as the root of the trouble and accordingly proposes a special kind of unemployment insurance. Sir Basil Blackett suggests, in his "Planned Money", that the lack of balance is more general and requires to be remedied by a currency based on a price index and managed with the view of maintaining stable prices. He also commends planning and co-ordination.

The next group of schemes arraigns unco-ordinated individualism as largely responsible for the present troubles. The schemes can conveniently be analysed into two sections, namely :

(a) Mr. Harold Macmillan's "Reconstruction" proposal, Fascism, the 'New Deal' in the United States, and the schemes of the 'New Britain' Group and of the 'Political and Economic Planning' Group.

(b) H. S. Jevons's 'Credit Income System', Communism, Technocracy, the programmes of the Labour 
Party and of the Socialist League and the scheme propounded by Edward Bellamy in "Looking Backwards" (published 1865).

Each of the schemes in section $(a)$ proposes a planned and co-ordinated economic system, but none of them, except that of the 'New Britain' group, involves a departure from the basis of private enterprise. Planning and co-ordination are also part of the Conservative and Liberal proposals, but for them the main source of our troubles is to be found in the international sphere. Both recognise, however, that the international situation is not capable of direct control, and therefore planning in some degree becomes a necessary national policy. Mr. Harold Macmillan proposes a compromise between the individualist and collectivist lines of thought. A Central Economic Council would aim at maintaining equilibrium between supply and demand by expanding demand, remembering that the worker is also a consumer. Labour would be represented on this Council, and while interference by workers in the daily management of industry is rejected, the industrial system would be humanised and opportunities for speculative profits much reduced.

The six schemes in section $(b)$, while they stress the failure of unco-ordinated individualism, are sharply distinguished from those in section $(a)$ by their emphatic assertion that the underlying causes of our present economic troubles are the "profit motive' and private ownership of the means of production. They regard a shortage and maldistribution of purchasing power as inevitable so long as these continue, and they therefore propose that the community should take over the ownership, if not the operation, of all production.

\section{University and Educational Intelligence}

Cambridge.-The Adams Prize for 1933-34 has been awarded to Dr. Sydney Goldstein, former fellow of St. John's College. Dr. L. Rosenhead, St. John's College, is highly commended for his essay. The prize is awarded every two years for an essay on some branch of pure mathematics, astronomy, or other branch of natural philosophy. The Sheepshanks Exhibition for astronomy, valued at about $£ 40$ for three years, has been awarded to S. W. Shivershwarkar, scholar of Sidney Sussex College. The successful candidate is required by statute governing the award to become a member of Trinity College.

An appointment to a Busk studentship in aeronautics will be made in July. The studentship,

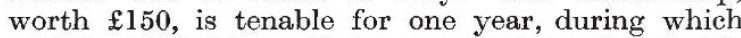
period the holder will be expected to devote his whole time to research. Forms of application may be obtained before June 8 from Prof. B. Melvill Jones, Engineering Laboratory, Cambridge.

LoNDon.-The following appointments have recently been made: Dr. C. H. Lobban, since 1926 University reader in civil engineering at King's College, to be professor of civil engineering, King's College, from October 1, 1935 ; Dr. A. St. G. J. McC. Huggett, since 1931 reader in pharmacology and member of the physiology staff in the University of Leeds, to be professor of physiology, St. Mary's Hospital Medical School, from October 1; Mr. J. P. Ross, since 1931 University reader in surgery at St. Bartholomew's Hospital Medical College, to be professor of surgery, St. Bartholomew's Hospital Medical
College, from October 1 ; Dr. H. A. Mess, since 1928 director of the Tyneside Council of Social Service, to be reader in sociology, Bedford College, from October 1 .

The title of professor of political economy in the University has been conferred on Mr. N. F. Hall, in respect of the post held by him at University College.

OXForD.-The scientific contributions of early members of the Queen's College formed the subject of Dr. R. T. Gunther's lecture last week, with especial reference to the work of Edmond Halley and Thomas Pennant who to a very large extent have the credit for having secured the publication of Newton's "Principia" and Gilbert White's "Natural History of Selborne". Sir John Floyer, the inventor of the pulse-watch and advocate of cold bathing, was also a member of the College.

Commonwealth Fund Fellowships tenable by British graduates in American Universities for two years beginning September 1935, have recently been awarded to the following, among others: Dr. F. X. Aylward (Liverpool) to Johns Hopkins University, in biochemistry ; Miss M. E. Francis (Girton College, Cambridge) to the University of California, in geography; A. R. Gemmell (Glasgow) to Rutgers University, in plant pathology; Dr. Ronald Grant (Queen Mary College, London, and Universities of Edinburgh and Leeds) to the University of Chicago, in zoology; J. G. M. Hamilton (Edinburgh) to Harvard University, in medicine; W. R. Hawthorne (Trinity College, Cambridge) to the Massachusetts Institute of Technology, in engineering; Miss G. G. Leybourne (University College, Cardiff) to the University of Chicago, in statistics; F. V. Price (New College, Oxford) to Princeton University, in physics ; M. H. L. Pryce (Trinity College. Cambridge) to the Institute for Advanced Study, in mathematics ; G. D. Rochester (Armstrong College, Newcastle) to the University of California, in physics; E. D. Tagg (Claire College, Cambridge) to Princeton University, in mathematies; Harold Walke (University College, Exeter) to the University of California, in physics; Kenneth White (Queen's College, Oxford) to the University of Chicago, in economies; John Wilkinson (Armstrong College, Newcastle) to Harvard University, in botany; R. B. Williams (Corpus Christi College, and New College, Oxford) to Princeton University, in chemistry; Leslie Young (Imperial College of Science and Technology and University College, London) to Washington University, in biochemistry. R. B. Bryce (Toronto and St. John's College, Cambridge) has been awarded a British Dominions fellowship to Harvard University, in economics. The following have been appointed to fellowships tenable by candidates holding appointments in Government service overseas: W. E. Cohen (Western Australia, and Council for Scientific and Industrial Research, Australia) to the University of Wisconsin, in wood chemistry; H. C. Forster (Melbourne, and the Department of Agriculture, Victoria) to Iowa State College, in agriculture; J. G. Gibbs (New Zealand, and the Department of Agriculture, New Zealand) to the University of Minnesota, in agriculture; H. J. N. Hodgson (Melbourne, and the Engineering and Water Supply Department, South Australia) to Harvard University, in engineering; C. C. Wessels (Pretoria, and the Department of Agriculture, South Africa), in veterinary science. 